Proc. Estonian Acad. Sci. Geol., 2003, 52, 1, 42-62

\title{
Sea floor deposits in Keibu Bay and Nõva Bay (northwestern Estonia) and the adjacent offshore area
}

\author{
Jüri Kask ${ }^{\mathrm{a}}$, Tuuli Kalberg ${ }^{\mathrm{a}}$, Aado Talpas ${ }^{\mathrm{a}}$, Klaus Schwarzer ${ }^{\mathrm{b}}$, \\ and Carolyn Wegner ${ }^{\mathrm{b}}$ \\ ${ }^{a}$ Geological Survey of Estonia, Kadaka tee 82, 12618 Tallinn, Estonia; j.kask@egk.ee \\ ${ }^{\mathrm{b}}$ Christian-Albrechts-University of Kiel, Institute of Geosciences, Olshausenstr. 40, 24118 Kiel, \\ Germany; kschwarzer@corelab.uni-kiel.de
}

Received 29 November 2001, in revised form 28 June 2002

\begin{abstract}
Grain-size distribution of sea floor deposits of Nõva Bay and Keibu Bay, northwestern Estonia, is discussed. Based on grain-size statistics, the lateral and vertical distribution of different types of bottom sediments is shown and compared for the two bays. The bottom deposits consist mostly of sand $(80-100 \%)$. The proportion of silt and gravel is considerably smaller: up to $3 \%$ in Nõva Bay and up to $7 \%$ in Keibu Bay. In Nõva Bay medium sand predominates. Grain-size distribution of deposits is rather uniform and an obvious correlation exists between the occurrence of different fractions and the water depth. In Keibu Bay sand of different grain size prevails. Along the boundary between the mouths of the bays and the open sea, a belt of coarse sand runs parallel with the shoreline. Beyond this belt silt and clay are predominant.
\end{abstract}

Key words: Estonia, nearshore environment, Quaternary deposits, grain-size distribution, bottom deposits.

\section{INTRODUCTION}

During the last decades considerable progress has been made in the study of the West Estonian shelf. In the 1980s scientists of the Institute of Geology, Estonian Academy of Sciences, started to investigate the uppermost layers of the bottom deposits of Keibu Bay by using $2 \mathrm{~m}$ long cores taken with a vibrocorer. Based on the results obtained, geological sections of this part of the bottom deposits and maps of the sediment distribution were compiled (Raukas \& Hyvärinen 1992; Lutt \& Raukas 1993).

From 1985 to 1997 geological mapping of the shelf was carried out by the Geological Survey of Estonia using seismoacoustic sounding. At water depths below $10 \mathrm{~m}$, bottom deposits were sampled with a gravity corer and grip-scoop (Lutt \& Raukas 1993). 
The investigation of the shelf area of northwestern Estonia within the EU-funded BASYS (Baltic Sea System Study) Project started in 1996, with the aim of studying the sedimentological conditions along a transect crossing the mouth of the Gulf of Finland between Estonia and Finland. The sedimentological conditions are variable in this area, being influenced by Osmussaar Island and Neugrund Bank. Investigation of Neugrund Bank was initiated at the Geological Survey of Estonia in 1995.

\section{STUDY AREA}

The study area, Nõva Bay and Keibu Bay, lies in northwestern Estonia, between Ristinina and Põõsaspea capes (Fig. 1). Both bays are klint bays where Ordovician bedrock limestone crops out on peninsulas (Fig. 2). The eroded material is deposited in bayheads. The shoreline of Keibu Bay resembles a crescent; to the northeast the bay borders with Ristinina Cape and to the southwest with Toomanina Cape. Nõva Bay has a less dissected shoreline and borders with Põõsapea Cape in the southeast. The mouth of Nõva Bay is approximately $8 \mathrm{~km}$ and that of Keibu Bay $4.5 \mathrm{~km}$ wide. Owing to the neotectonic uplift of c. $2-3 \mathrm{~mm} / \mathrm{yr}$ (Vallner et al. 1988), the coastline has been prograding in northwestern Estonia, and ancient coastal formations and dunes are therefore located towards the inland. Despite the relatively small length of the shoreline of the two bays, the nearshore area is rather variable.

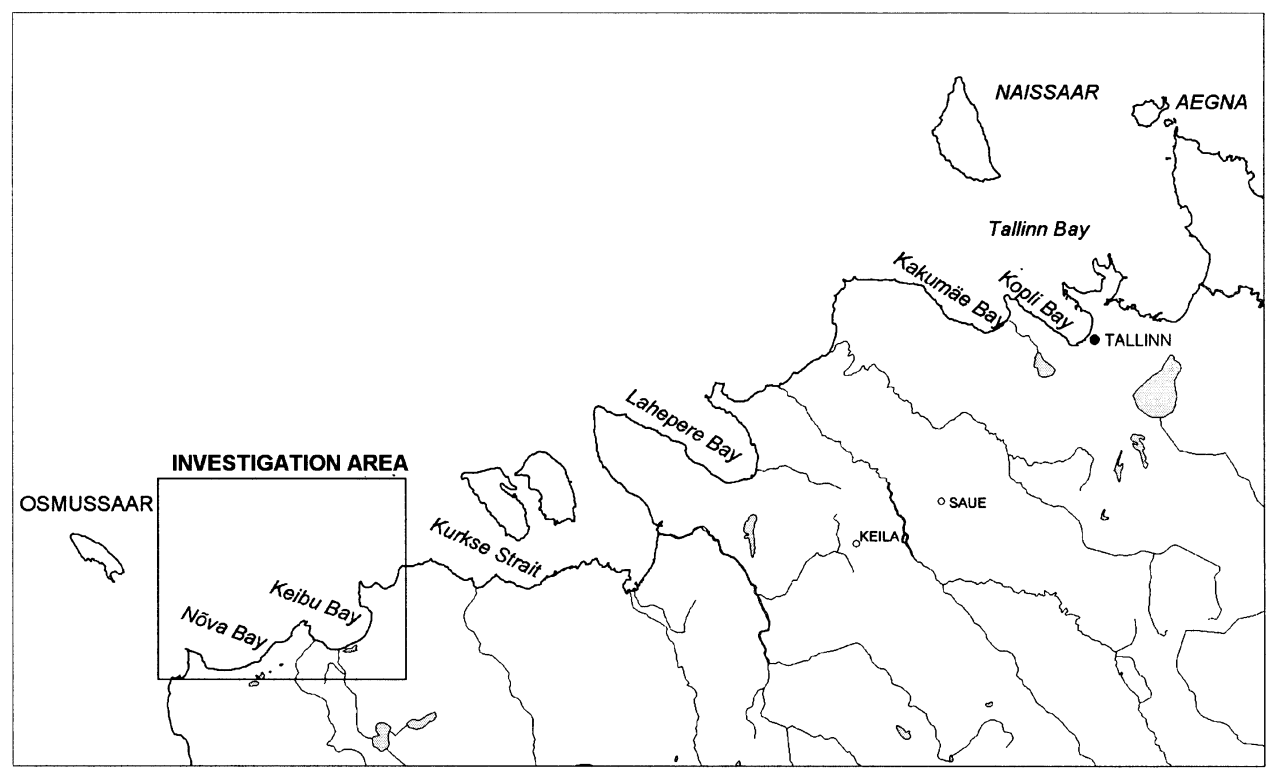

Fig. 1. Location of the investigation area. 
Because of the neotectonic uplift (Vallner et al. 1988) Estonian coasts have formed under the conditions of sea regression during the last 5000-6000 years. The present situation is similar - new relief forms emerge in the zone of wave action. In Keibu Bay and Nõva Bay the seabed is smooth, deepening gradually towards the open sea. The arbitrary boundary between the open sea and the bays is the $10 \mathrm{~m}$ isobath. The bedrock cropping out on capes continues on the sea floor, forming wave-cut benches. Two prominent shoals occur in the eastern parts of Keibu Bay and Nõva Bay, considerably influencing the sedimentation in this region. These drumlin-like moraine hillocks with a bedrock core are Sundstein Bank between Põõsaspea Cape and the southeastern tip of Osmussaar Island, and Sundgrund Bank to the northwest of Toomanina Cape (Fig. 2).

A variety of coastal formations occur in the observation area: cliffs on capes (Fig. 3), shingle beach ridges (pebbly shore) in lateral parts of the bays, gradually replaced by till shores (Fig. 4), and sandy shores in bayheads (Fig. 5). The exposed carbonate bedrock is subject to intense erosion, therefore pebbly shores prevail in the areas bordering with these regions. In some places contemporary marine deposits are missing and Upper Pleistocene varved clays are exposed on the seabed.

\section{MATERIAL AND METHODS}

The bottom sediments of Keibu Bay and Nõva Bay were sampled jointly by the Geological Survey of Estonia, the Institute of Geosciences of Kiel University, and the Estonian Marine Institute in 1997-99 within the framework of the BASYS project. During the first marine expedition in March 1997, samples were collected by grip-scoop at 44 locations in the nearshore area. Sediments were analysed at the Laboratory of the Geological Survey of Estonia, benthic animal communities were studied at the Estonian Marine Institute (Kotta et al. 1999). In June 1997 another expedition on board the r/v Littorina of Kiel University was carried out. Samples were collected at 35 points in the open sea area close to Keibu Bay and Nõva Bay. A sidescan sonar (KLEIN 595) and boomer system (EG \& G) were used to study the lateral and vertical distribution of deposits. During both cruises the topmost bed $(0-10 \mathrm{~cm})$ of bottom deposits was sampled. In June 1998 the mouths of the bays were investigated aboard the r/v Littorina by vibrocoring, bathymetrical surveying, sidescan sonar and seismoacoustic (boomer) measurements. In July 1998 and August 1999, the region between Neugrund Bank and the mainland was studied with a sidescan sonar aboard the r/v Mare of the Estonian Maritime Museum and samples were collected by grip-scoop and scuba diving.

The present study uses grain-size classifications taken as a standard at the Institute of Geosciences of Kiel University (Schwarzer 1989). A total of 120 samples were analysed at the Laboratory of the Geological Survey of Estonia. The grain-size composition was determined by sieving according to ASTM 
standard. The $>0.063 \mathrm{~mm}$ fraction was screened with a set of screens used also in similar previous studies (Schwarzer 1989).

The results of the grain-size distribution analyses were processed following the method of statistical moments (Paap 1969; Lewis \& McConchie 1994). The distribution of different fractions at different depth intervals $(0-2,2-5,5-10$, $10-15,>15 \mathrm{~m}$ ) was analysed in order to find out the relations between water depth and grain-size composition. The lateral distribution of different fractions was studied as well. Grain-size sorting was estimated based on the classification by Friedman et al. (1992).

\section{GEOLOGICAL SETTING}

The bedrock is represented by Ordovician carbonate rocks cropping out as E-W belts. Keibu Bay and Nõva Bay lie in ancient buried valleys that head towards inland and are filled with glacial, glaciolacustrine, and marine deposits. Linear bedrock depressions are located in tectonic fault zones (Raukas \& Teedumäe 1997).

Late- and post-glacial deposits are spread in the whole basin, while marine deposits are distributed only locally (Fig. 6). During the Late Weichselian, tills and glaciolacustrine sediments were deposited. During the Pleistocene, the region was subject to extensive glacial erosion and till formed probably at the Palivere Stade of the last glaciation (Raukas \& Teedumäe 1997). The 15-20 m thick till is mainly dark-grey, sometimes also somewhat brownish, and rich in clay. In the southern part of Neugrund Bank and to the north of Osmussaar Island the till is bluish-grey or blue and contains abundant pieces of sandstone, less often crystalline rocks. The amount of well-rounded coarse-grained material is small, the proportion of sand and silt is almost equal.

The till (in places the bedrock) is overlain by glaciolacustrine or Baltic Ice Lake deposits, comprising mainly beige or brownish clays exhibiting a distinct varved structure. In the lower part of the described complex lenses of till or interbeds of gravel and sand are rather common. The middle part of the complex is represented by greyish-beige clay with silt interbeds, while the upper part consists of mainly pinkish-beige clay, in places with light-bluish interlayers (socalled particoloured complex). The thickness of the varves and the amount of sand increase towards the base. The outcropping Late Weichselian and Holocene clays are overlain by a thin layer of mixed sand with gravel (so-called residual deposit) of yet unknown origin. In the same area also iron and manganese nodules of various shape and size are found.

The 5-8 m (locally up to $40 \mathrm{~m}$ ) thick glaciolacustrine clays were formed under conditions of intense sedimentation (onlap structures) and are easily identified in seismoacoustic records. The contact of clays with the underlying sediments is clear and the overlapping can also be observed on the records of low-frequency seismoacoustic sounding. The high-frequency seismoacoustic sounding has 
revealed two seismostratigraphic units. The upper unit (Baltic Ice Lake deposits) of smaller density is somewhat more transparent than the lower unit. Some seismoacoustic logs show a distinct surface that could be considered as a boundary between the Baltic Ice Lake and "local" ice lake deposits. Further offshore, 15-23 m below sea level, the glaciolacustrine clays are often eroded.

The Holocene is represented by the Yoldia Sea and Ancylus Lake deposits (mIVy + LIVan) (Raukas \& Teedumäe 1997). The predominantly grey Yoldia Sea deposits comprise beige or brownish-grey pelites and grey laminated silt. Their lower boundary can be identified by thin silt or sand beds (evidence of the so-called Billingen event), marking also the Pleistocene-Holocene boundary. These beds are overlain by black or dark-grey clay containing hydrotroilite. The Yoldia Sea deposits have formed under freshwater conditions. Clay material prevails, but the proportion of silt has increased considerably as compared with the above-described Baltic Ice Lake and local ice lake deposits.

The Ancylus Lake deposits, ranging in thickness from some centimetres to 4-5 $\mathrm{m}$, begin with the so-called lower hydrotroilite bed having a distinct undulating lower boundary (discontinuity surface). Seismoacoustic records show that in some places they are lying unconformably on the Yoldia Sea deposits. The distribution of single beds is not continuous; sporadically some of them are missing. In some places the hydrotroilite beds are not clearly distinguishable or hydrotroilite is strongly dispersed. The distribution area of Ancylus Lake deposits coincides with that of the glaciolacustrine clays.

The Yoldia Sea deposits form the lowermost part of the Holocene complex. Their pollen spectrum displays Preboreal flora, which replaces the Late Weichselian flora already before the Billingen event. The lower hydrotroilite bed in the Ancylus Lake deposits serves as the upper boundary of the distribution of this flora in the vertical section. The rest of the Ancylus Lake deposits have formed during the Boreal.

The Litorina and Limnea Sea deposits were formed during the Atlantic, SubBoreal, and Sub-Atlantic periods. They are characterized by a relatively high content of organic matter and numerous hydrogen sulphide occurrences, as well as microbedded texture. High-frequency seismoacoustic sounding records revealed parallel bedding. The contact with the underlying beds is sharp and clear. Further offshore occur greenish and greenish-grey clayey and silty deposits, the upper part of which consists of liquid or liquid-plastic pelitic material. Approximately $1-3 \mathrm{~cm}$ thick brownish-yellowish oxidation beds with up to $50 \%$ fine sand are rather common.

To the north of Neugrund Bank, the amount of pelitic material exceeds $75 \%$, while to the south of the bank silt with clay and sand is distributed. To the south of the underwater klint, silt and mixed sand occur. Sand is deposited at the heads of Keibu Bay and Nõva Bay. The thickness of sand varies, reaching in places 4-5 m. Almost all sand fractions are present, but medium and coarse sands prevail.

Tentatively, the complex of marine deposits can be divided into the lower (mainly greenish) and upper (dark-grey to black) parts. The colour of the deposits depends on the ratio of bi- and trivalent ferric ions. The distribution of late- 
and post-glacial deposits has clearly regressive character - the area of younger deposits is decreasing and their outcrop areas are moving towards shoals or foots of underwater shoal slopes.

\section{SEDIMENTARY CONDITIONS}

Sedimentation on the shelf is controlled by a number of processes, first of all by the direction, continuation, and strength of winds. These factors influence the character of waves, partly water level fluctuations and local currents. On the Northwest Estonian coast westerly winds dominate (Jõgi \& Tarand 1995). Storms (wind speed more than $20 \mathrm{~m} / \mathrm{s}$ ) are rare and occur mostly in autumn and winter.

The coastal areas of northwestern Estonia are exposed to waves approaching from the open sea. Osmussaar Island, situated to the northwest of Nõva Bay, somewhat shelters the bays from strong westerly storms (Fig. 7), but during severe westerly and northwesterly storms wave height can reach up to $5 \mathrm{~m}$, and the wave length (L) can be up to $100 \mathrm{~m}$ and more. Waves begin to influence the seabed in a depth equal to L/2 (Komar 1976). Therefore, most of the studied area is subject to wave activity affecting sediment transport. Interior parts of the bays are relatively shallow, but at the tips of peninsulas the seabed is steeper and the influence of waves on coastal processes is stronger. Shingle ridges on the capes give evidence of wave energy under rough sea conditions.

In northwestern Estonia westerly winds prevail, consequently, currents are orientated in the same direction. Changes in wind speed and direction have relatively short-term influence on the currents. Tides are not clearly expressed in northwestern Estonia. However, aperiodic high and low water stands considerably affect the coastal zone. The water level lowers during long-range (several days) northerly and easterly winds, while high water level is due to long-range southerly or westerly winds. During heavy storms the high water in the bays may exceed the regular water level by more than $1 \mathrm{~m}$. The fluctuations of water level are rather regular. Annually two maxima (in August and December-January) and two minima (April-May and October) are registered. Together with wave action, these are the major factors controlling erosion and deposition.

Normally the Estonian coastal waters are covered with ice in winter, which on one hand protects the shore from wave action and on the other hand acts as crushing agent causing considerable coastal damages - erosion of the shore and transport of sediment to the shore as well as offshore. For example, when the water is frozen to the bottom during shallow water periods in winter (water depth $>0.5 \mathrm{~m}$ ), material of different grain size (from clay to boulders) is incorporated inside the ice and carried offshore by drifting ice. Thus, in sandy deposits boulders and cobbles are found, which generally are not characteristic of this sediment type. Drift ice also loosens bottom sediments, thus creating favourable conditions for erosion and deposition processes. Thickness of the ice may vary greatly, in places reaching $1 \mathrm{~m}$. Hummocked ice may form up to $15 \mathrm{~m}$ high piles on the shore. 


\section{SOURCES OF SEDIMENT}

The bottom deposits of Keibu Bay and Nõva Bay have been formed as a result of erosion of bedrock limestones cropping out on peninsulas and ancient beach ridges, and tills and varved clays exposed on the seafloor. The proportion of the material carried into the bays by rivers and brooks is considerably smaller. The role of the biggest river, the Nõva, in the sediment transport increases during periods of high water level. Minor brooks carry some material into bayheads as well.

Shorelines which are subject to erosion are the eastern shore of Põõsaspea Cape $(1.2 \mathrm{~km}$ shore stretch), western shore of Dirhami Cape $(1 \mathrm{~km})$, western shore of Keibu Bay $(1.4 \mathrm{~km})$, and a $1.5 \mathrm{~km}$ stretch of the shore at Keibu Village. The length of the shoreline of Keibu Bay is $9.5 \mathrm{~km}$ (sandy shore $-4.8 \mathrm{~km}$, pebbly shore $-2.4 \mathrm{~km}$, till shore $-2.3 \mathrm{~km}$ ), $7.2 \mathrm{~km}$ of which is accumulative. Coastal deposits have formed on account of abrasion of tills and varved clays cropping out in the nearshore and partly on the shore (the content of the $0.1-1.0 \mathrm{~mm}$ fraction in the till is 30-40\%). Approximately $1250-1300 \mathrm{~m}^{3} / \mathrm{yr}$ of sand is deposited on the shore. Measurements along coastal profiles show that, according to deposition, the shoreline has moved offshore by $0.8 \mathrm{~m}$ in Keibu Bay during the last 10 years. At the same time on its western shore the bluff in the till retreated by only $0.5 \mathrm{~m}$. This phenomenon is characteristic of the straightening-deposition coast where erosion occurs on capes and deposition at bayheads. The shoreline of Nõva Bay is $11 \mathrm{~km}$ long (sandy shore $-8.5 \mathrm{~km}$, sandy-pebbly shore $-0.5 \mathrm{~km}$, pebbly shore $-0.8 \mathrm{~km}$, rocky shore $-1.2 \mathrm{~km}$ ). Approximately $2400-2500 \mathrm{~m}^{3}$ of sand is annually deposited at the bayhead.

\section{DISTRIBUTION OF BOTTOM DEPOSITS}

In Keibu Bay and Nõva Bay erosion, deposition, and transport areas can be distinguished. Older deposits and bedrock are eroded on the tips of peninsulas and on underwater shoals, but deposition prevails in the areas with lower wave activity (bayheads). Erosion and deposition areas occur relatively regularly, depending on the geological structure and the hydrodynamic conditions. For a long period the cliff on Ristinina Cape has been subject to wave activity and a wave-cut bench has formed in the nearshore. High beach ridges of eroded material have been formed on the eastern shore of Keibu Bay. Erosion is intense also in the region of Põõsaspea Cape, where the material of ancient beach ridges is re-deposited and is partly carried away to the nearshore.

Under conditions of moderate wave activity (onshore wind speed 5-9 m/s), sand is deposited at the bayheads, while storms (wind speed over $20 \mathrm{~m} / \mathrm{s}$ ) induce an offshore transport which extends to outside the bays. The thickness of the deposited sand layer outside the bay is considerable.

In northwestern Estonia moderate onshore wind conditions prevail and during those periods wave activity causes sediment transport only in shallow waters. 


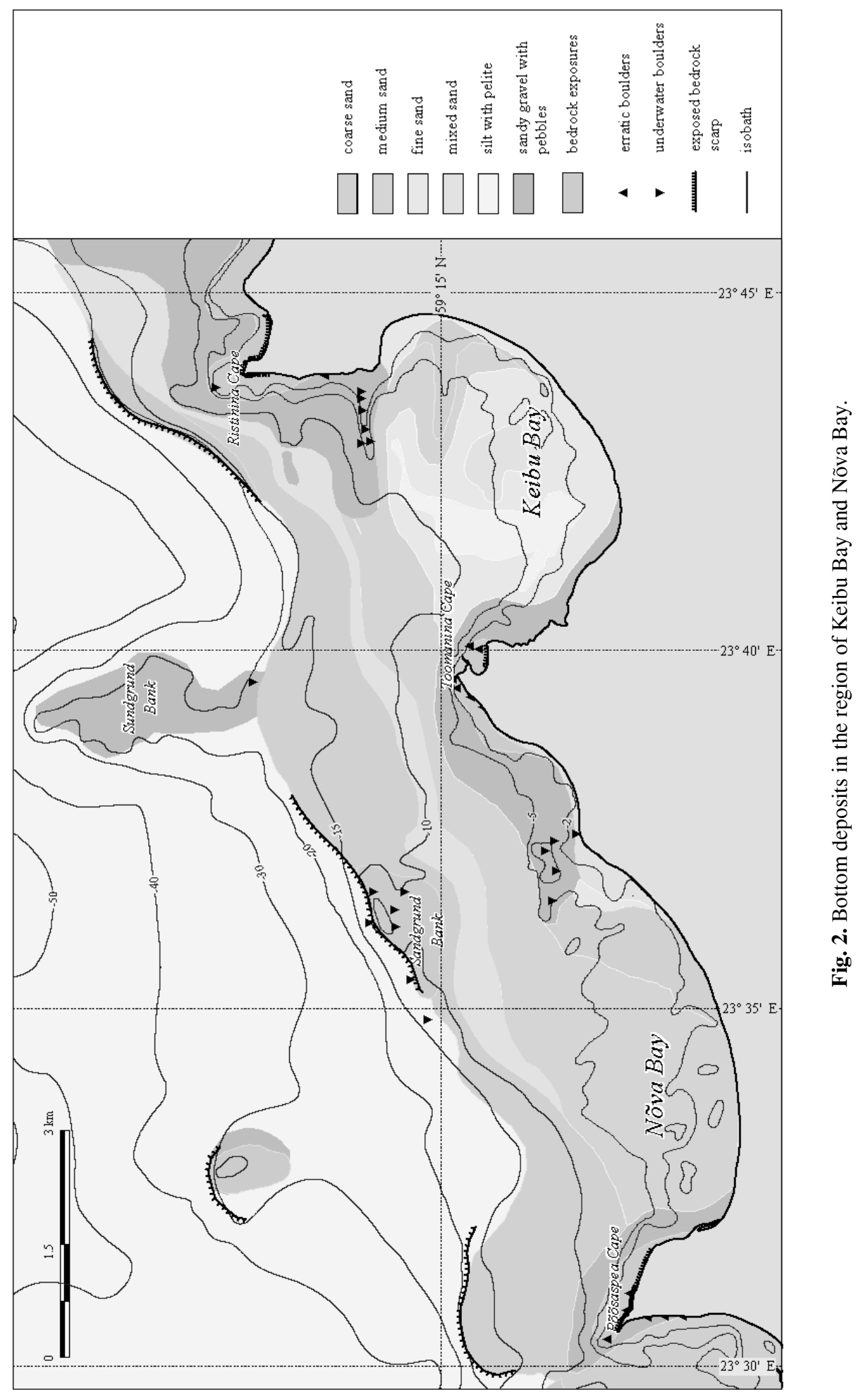




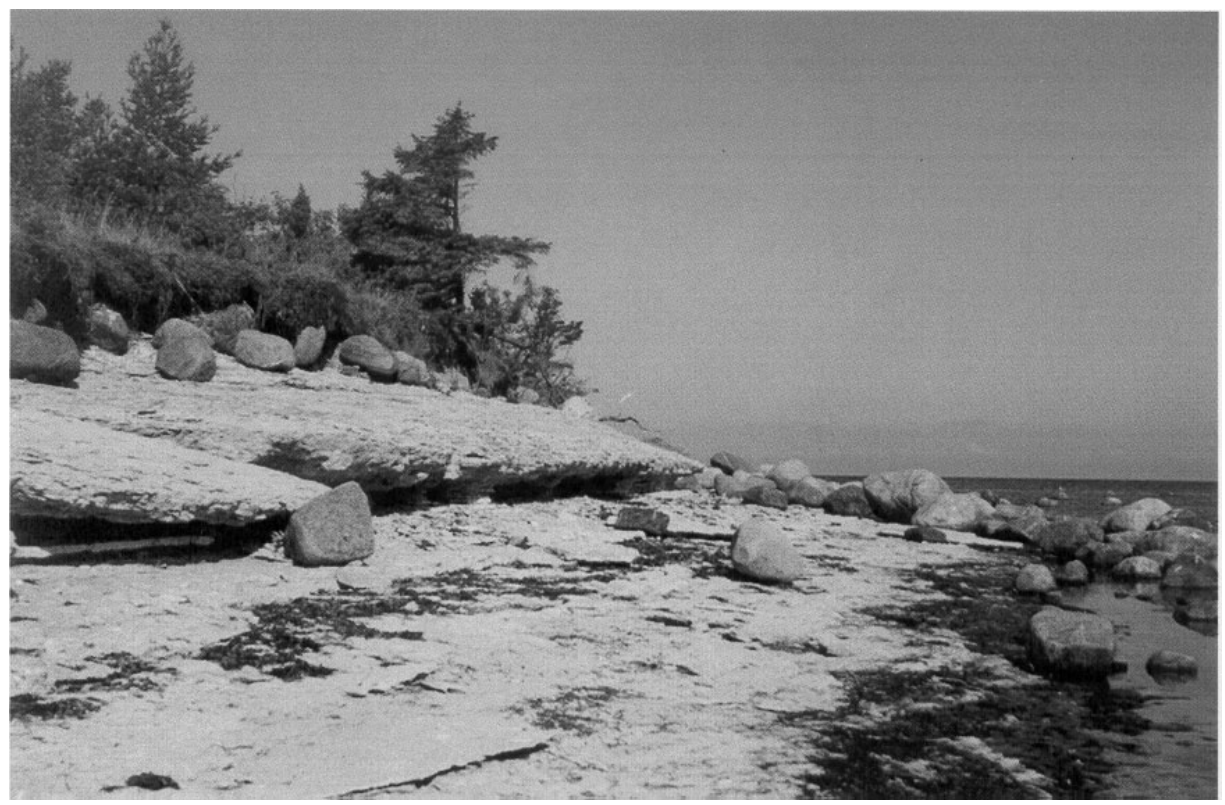

Fig. 3. Ristna Cape is situated in the eastern part of the investigation area, where bedrock limestone is exposed on the ends of peninsulas as small cliffs. The abraded material is carried towards inner parts of bays.

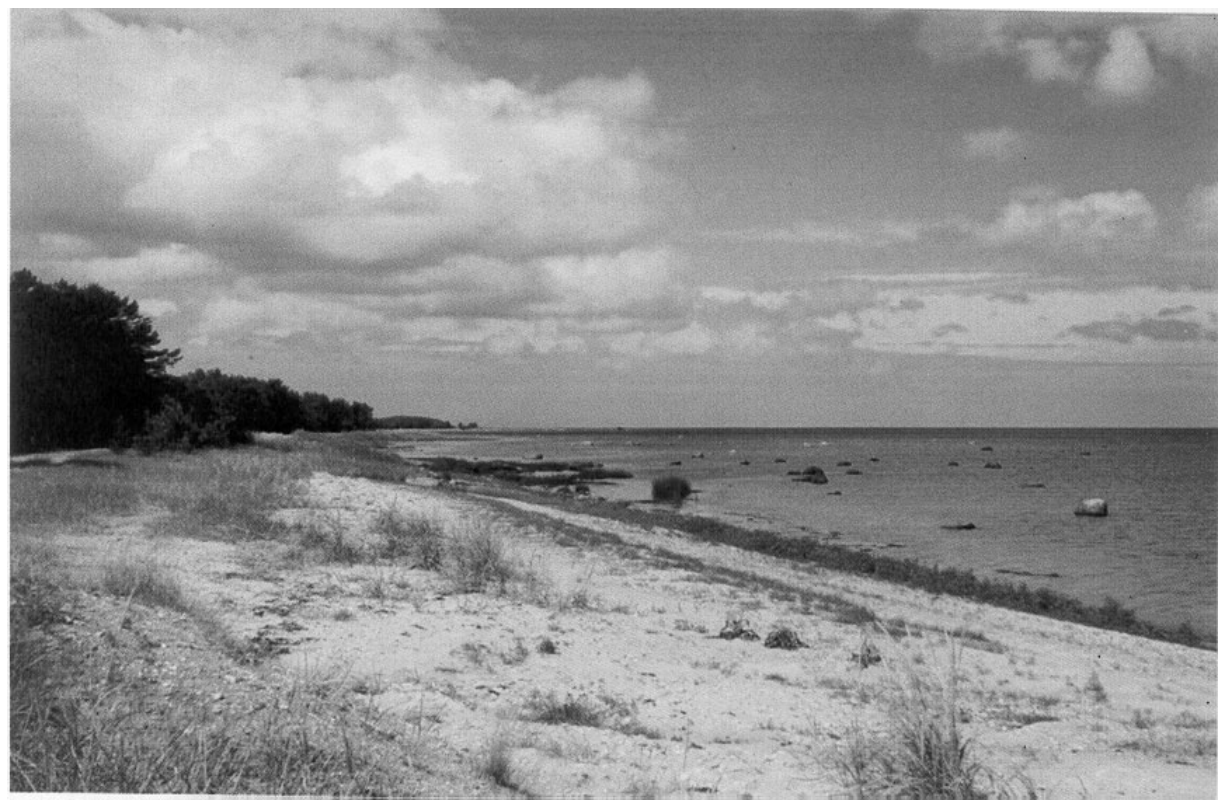

Fig. 4. Till shores are spread in a limited area in northwestern Estonia, mostly on lateral shores of bays, and serve as abrasion and sediment transport areas. 


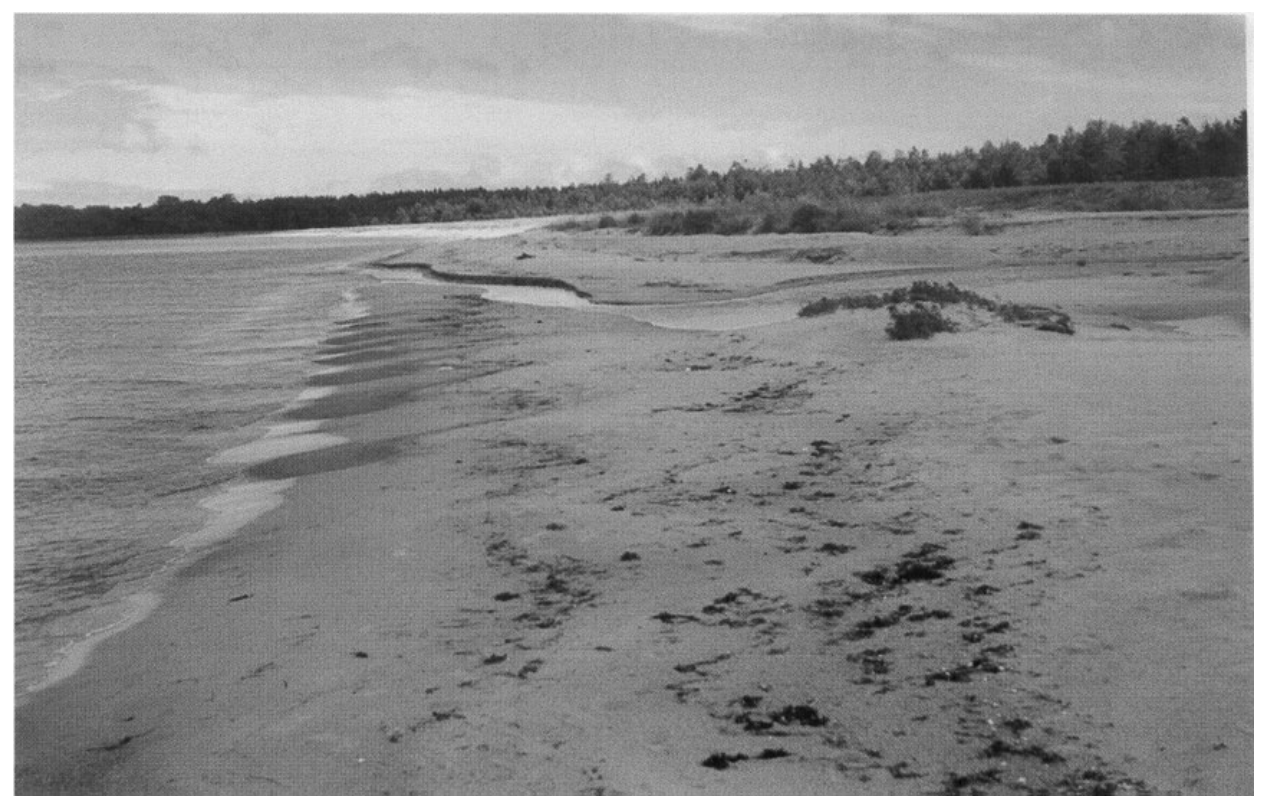

Fig. 5. Sandy shores are widely distributed in inner parts of bays (on lateral shores and bayheads).

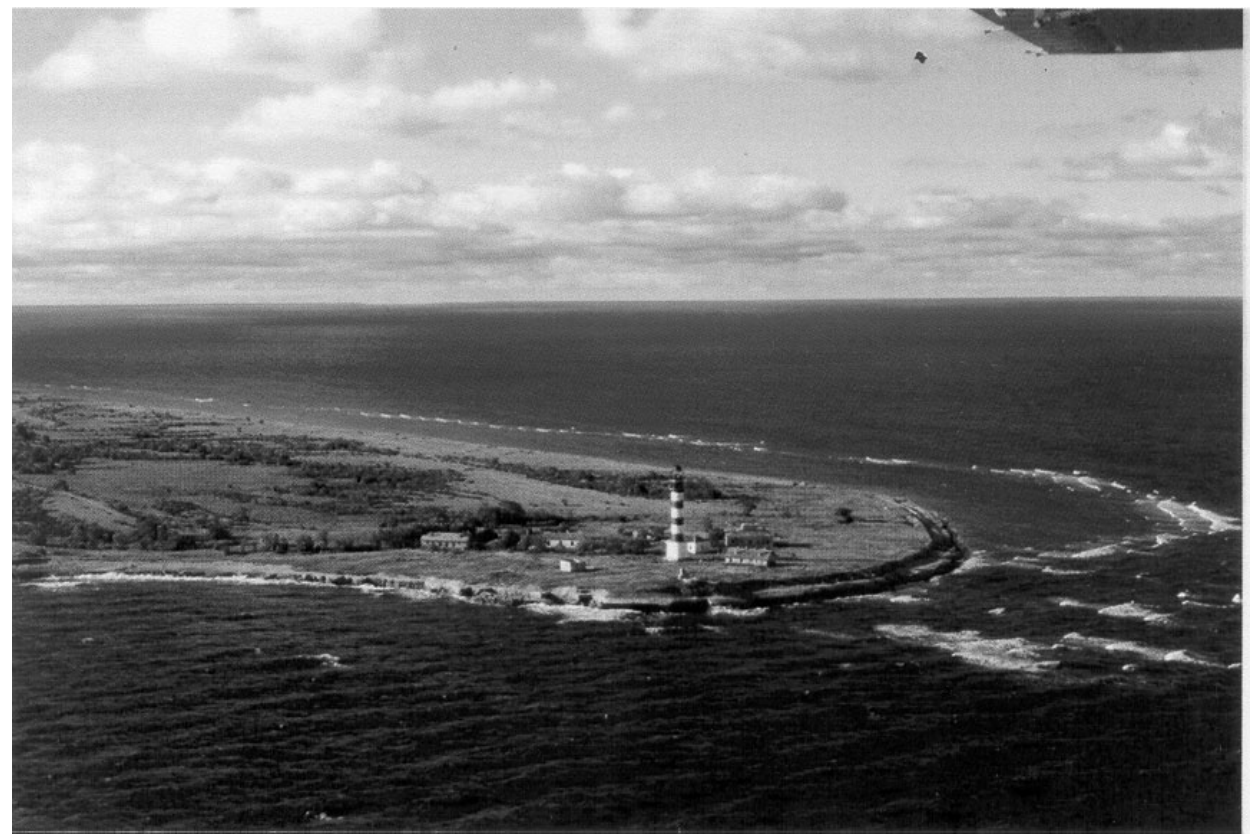

Fig. 7. Osmussaar Island is situated to the northwest of Nõva Bay. The island protects the bays from strong westerly storms. Bedrock of Osmussaar Island is represented by limestone and the Quaternary cover by gravel and pebbles forming beach ridges. 


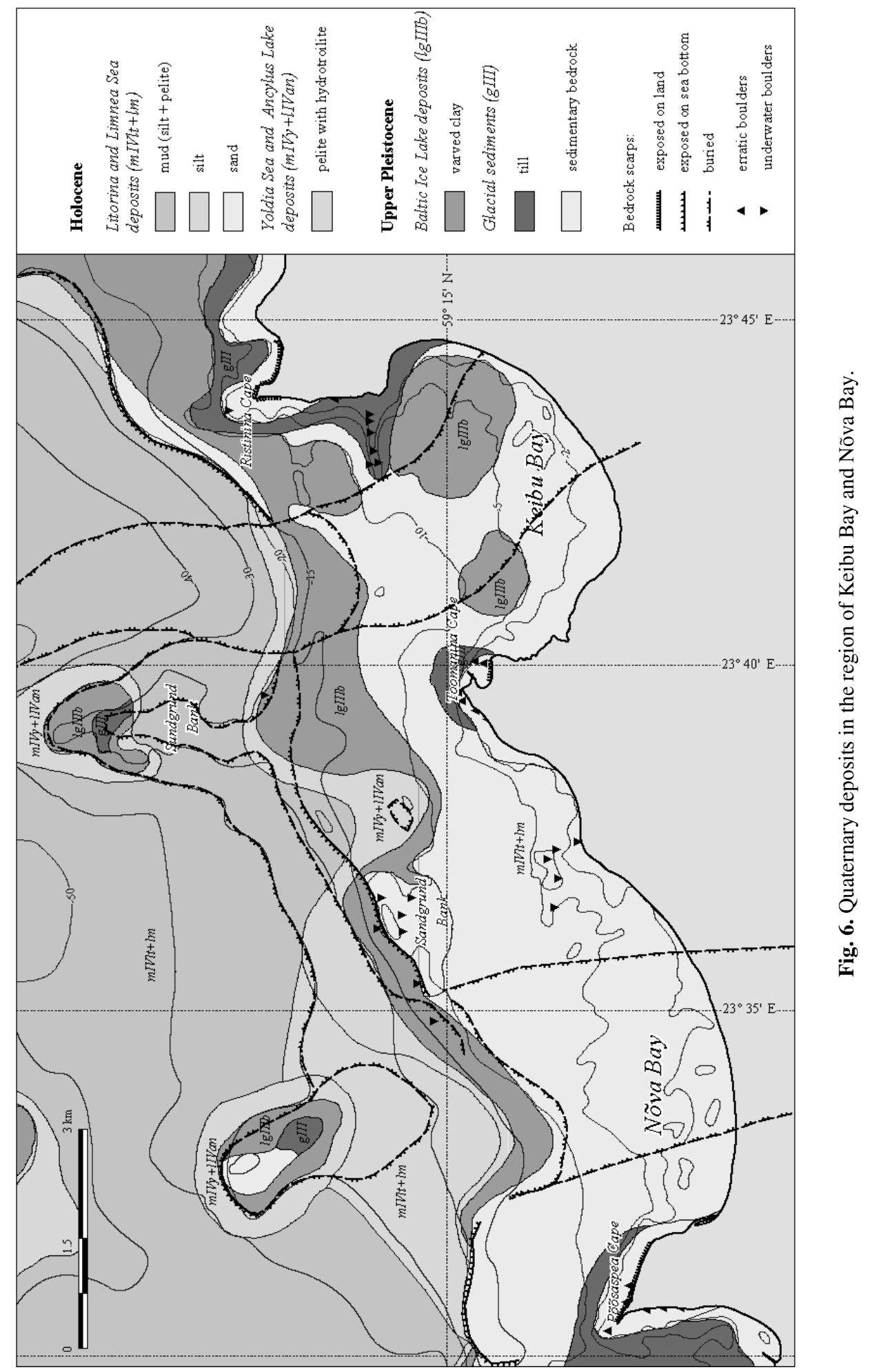


Therefore, only a relatively narrow belt close to the shoreline is subject to waveinduced sediment transport. According to Hjulström (1938, cited in Seibold \& Walger 1962), merely low-energy conditions are required to transport fine sand $(0.063-0.200 \mathrm{~mm})$. This explains the distribution of a narrow belt of fine sand at the head of Keibu Bay. The deposits in deeper, interior parts of the bays are subject to wave activity when wind speed reaches $16-20 \mathrm{~m} / \mathrm{s}$ and the wavebreaking occurs at a water depth of 8-12 m.

The distribution pattern of bottom deposits in Keibu Bay is more variable than in Nõva Bay. In Keibu Bay zones are formed by different grain-size

compositions. This bay is less exposed to wave activity. Although the axis of Keibu Bay is NW-SE orientated, the progradation of the waves is hindered by the relatively narrow mouth of the bay and by the shoal in its northwestern part. Thus, waves caused by strong westerly and northwesterly winds lose most of their energy in the bay mouth, eroding bottom deposits and bedrock exposed on the tips of capes.

The wave energy decreases towards the bayheads, but heavy storms combined with high water level carry the eroded material to the upper beach where it is deposited in beach ridges. The wave activity is evidenced by shingle beach ridges on the capes, which are especially conspicuous (up to 3-4 m high) on Ristinina Cape. The ridges on Põõsaspea Cape are lower, possibly due to the minor exposure to wind and wave activity.

A wide belt of coarse sand occurs between the 10 and $15 \mathrm{~m}$ isobaths, bordering shoreward with a belt composed of medium sand and seaward with a belt composed of silt. The belt of coarse sand coincides well with the outcrop area of the Baltic Ice Lake deposits. Silt occurs at water depths below $15 \mathrm{~m}$. Coarser deposits (gravel, pebbles, mixed sand), supposedly of residual origin, are found on the slopes of bedrock shoals.

\section{GRAIN-SIZE COMPOSITION OF BOTTOM DEPOSITS AND DISTRIBUTION OF DIFFERENT GRAIN-SIZE FRACTIONS}

The bottom deposits of Keibu Bay and Nõva Bay consist mainly (84\% of analysed samples) of sand of different grain size (Fig. 8). In general, the amount of silt and gravel is small. In Nõva Bay deposits with a high silt content (30-90\%) occur in areas below the $15 \mathrm{~m}$ water depth. The amount of gravel in these deposits is very small. In Keibu Bay, however, at the same depth, the content of gravel is higher $(20-70 \%)$ and the amount of silt is only 10-20\%. In this bay, from the shoreline to the $2 \mathrm{~m}$ water depth, the proportion of gravel is mostly below $20 \%$, reaching in some cases $20-40 \%$, rarely even $90 \%$, while the percentage of silt remains low. The deposits described above may originate from erosion of tills in the nearshore.

In Keibu Bay bottom deposits are represented mainly ( $>80 \%$ ) by different sand fractions covering the whole grain-size spectrum of sand. In the $0-2 \mathrm{~m}$ water depth medium sand is very rare. In the more open sea, bordering the mouth 
of Keibu Bay, coarser sand fractions prevail at depths of $10-15 \mathrm{~m}$. Various amounts of mixed sand are found at almost all water depths.

In Nõva Bay the grain-size spectrum of different sand fractions is much narrower (Fig. 9). Generally, two areas can be distinguished according to the

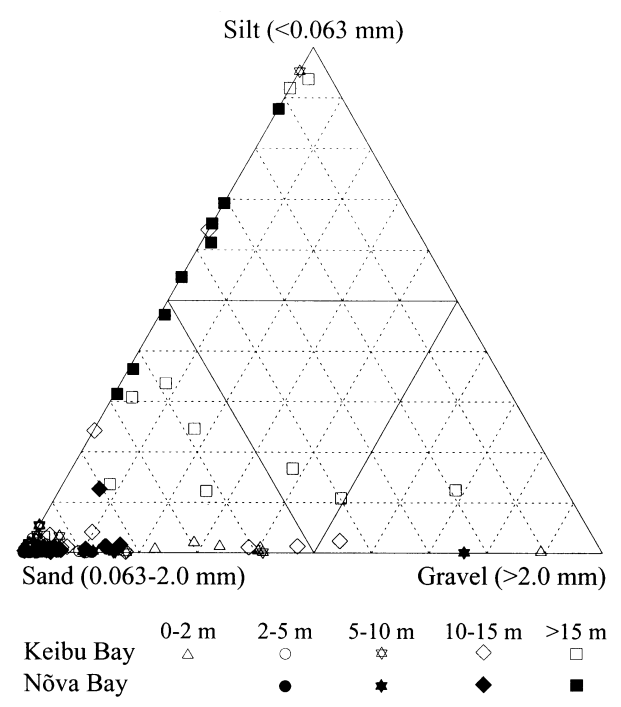

Fig. 8. Distribution of different fractions of bottom deposits at different water depths.

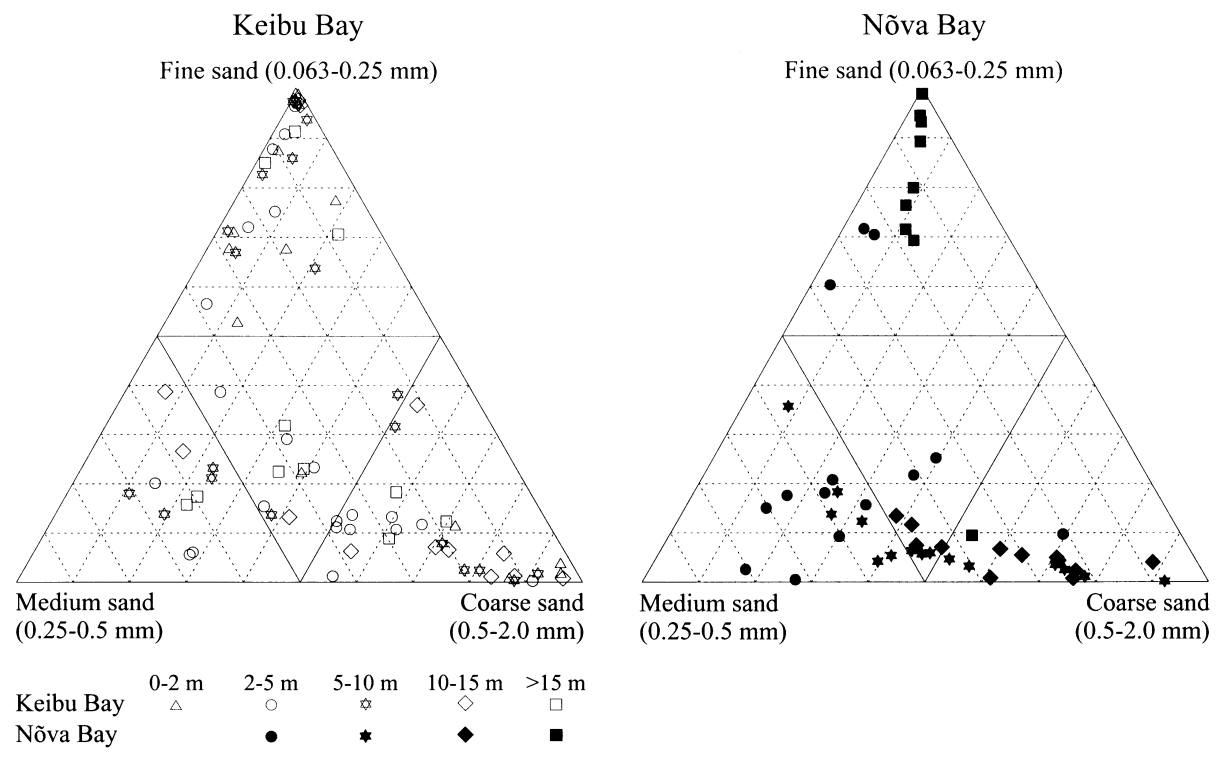

Fig. 9. Distribution of sand fractions in the bottom deposits of Keibu Bay and Nõva Bay at different water depths. 
amount of fine sand in the bottom deposits. The proportion of fine sand exceeds $70 \%$ at water depths below $15 \mathrm{~m}$ and locally at a depth of $2-5 \mathrm{~m}$, but is less than $20 \%$ between the $2 \mathrm{~m}$ and the $15 \mathrm{~m}$ depth contours. At the 10-15 m water depth coarse sand prevails and at the 2-5 m depth medium sand predominates (Fig. 9).

The bottom deposits of Keibu Bay show a very irregular distribution of different grain-size fractions between the $2 \mathrm{~m}$ and $15 \mathrm{~m}$ water depth and no correlation between grain-size spectra and water depth is observed here. However, the relationship between the grain-size composition and water depth is somewhat better in the shallowest part of the sea (depth 0-2 m; Fig. 10), where fine sand $(0.25-0.063 \mathrm{~mm})$ prevails. It should be noted that below $15 \mathrm{~m}$ coarse fractions are found only in the Sundgrund Bank area, obviously originating from exposed till (Fig. 11). In Nõva Bay (Figs. 11 and 12) the grain-size spectra are much narrower than in Keibu Bay. A particular fraction prevails at each water depth interval: medium sand $(0.5-0.25 \mathrm{~mm})$ at $2-5 \mathrm{~m}$ (Fig. 12), coarser fractions $(1.0-0.5$ and $2.0-1.0 \mathrm{~mm})$ at $5-10$ and $10-15 \mathrm{~m}$, and silt $(<0.063 \mathrm{~mm})$ at depths below $15 \mathrm{~m}$.

The bottom deposits of Nõva Bay are considerably better sorted than those of Keibu Bay (Figs. 13 and 14). Consequently, the facies diversity is higher in Keibu Bay. The grain-size distribution of samples from water depths of 2-15 m are almost identical for both bays, but below $15 \mathrm{~m}$ the sorting is better in Nõva Bay (Fig. 11).

The bottom deposits at water depths below $15 \mathrm{~m}$ in Nõva Bay are represented by silt. Between the $10 \mathrm{~m}$ and $15 \mathrm{~m}$ depth the sorting coefficient of bottom deposits is approximately 1 (medium sorting) and the $0.25-0.5 \mathrm{~mm}$ fraction prevails (see Figs. 13 and 14). In the $2-5 \mathrm{~m}$ water depth the grain size of the bottom deposits is $0.2-0.7 \mathrm{~mm}$ and the sorting coefficient is $0.5-1$. Here the sediments are better sorted in the shallow parts of the bays, in Nõva Bay also

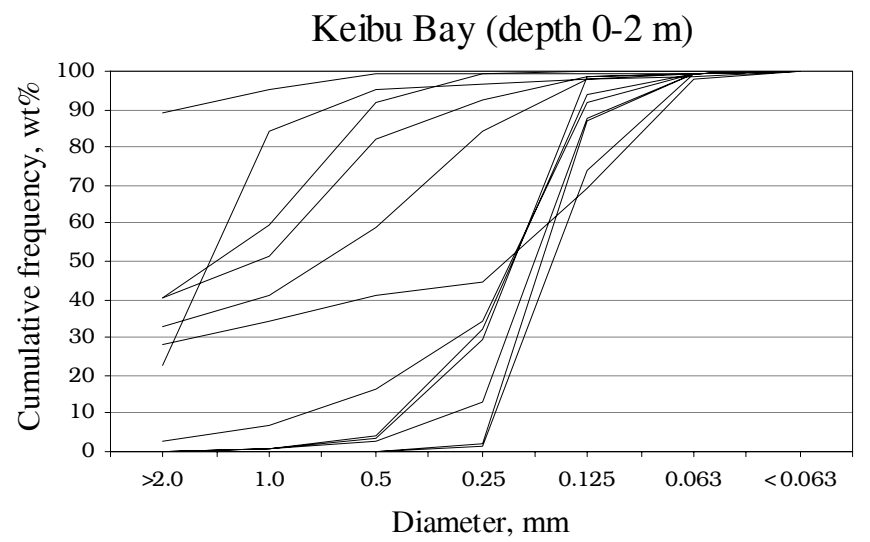

Fig. 10. Cumulative curves of grain-size distribution in the bottom deposits of Keibu Bay in the 0-2 m water depth interval. 

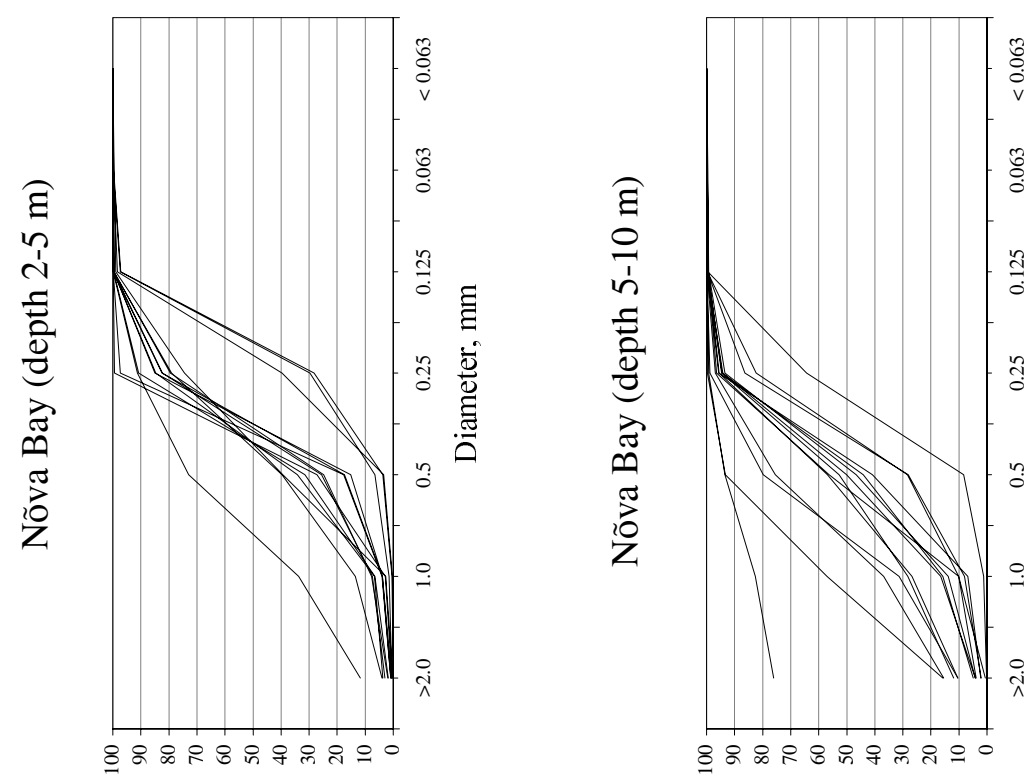

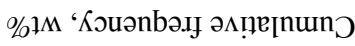

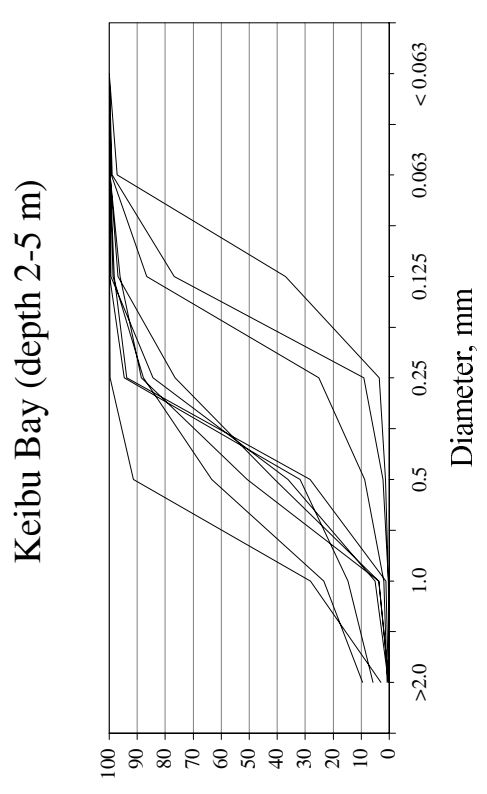

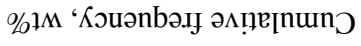

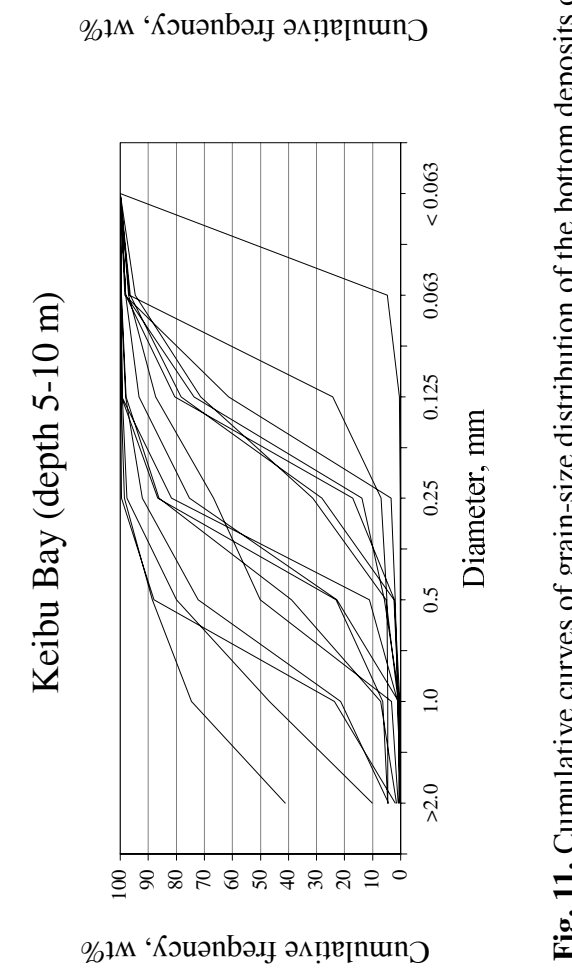



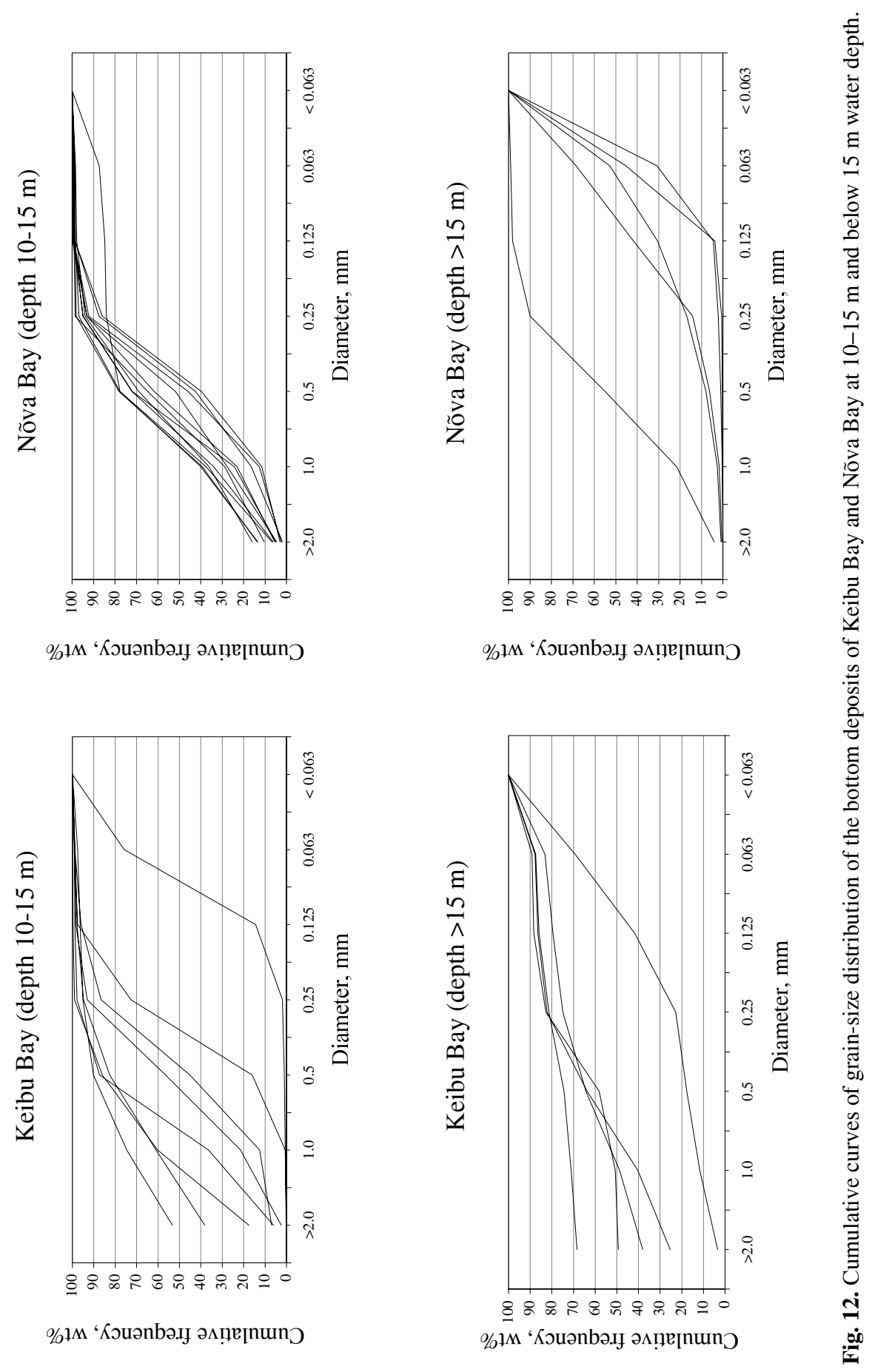
in its central part, and in the open sea bordering the bay below the $15 \mathrm{~m}$ water depth. Poorly sorted bottom deposits occur mainly on the western and northwestern slopes of Sundgrund Bank and at the head of Keibu Bay.

In Keibu Bay higher contents of silt $(<0.063 \mathrm{~mm})$ in the bottom deposits were recorded between Toomanina and Ristinina capes, i.e. in the bay mouth area. Previous investigations (Lutt 1992) have yielded similar results for the same area: the content of the $<0.05 \mathrm{~mm}$ fraction reaching $30 \%$. Silt is most distributed in the open sea, which can be seen in the respective cumulative curves of grainsize distributions and the ternary diagram (Figs. 8 and 11). In other parts of the investigation area the amount of silt is small.

The content of fine sand and medium sand $(0.063-0.25 \mathrm{~mm})$ is higher in Keibu Bay, where two distribution areas can be distinguished. One of them is in the shallow $(<2 \mathrm{~m})$ nearshore bayhead parallel to the waterline, the other is located between Toomanina Cape and the eastern shore of Keibu Bay, mainly between the $5 \mathrm{~m}$ and $10 \mathrm{~m}$ depth contours. The fine sand fraction makes up 50-85\% of deposits in this area, while in the open sea it averages $10 \%$, seldom reaching $25 \%$. The bottom deposits of Nõva Bay are poor in fine sand, except for single spots on the eastern shore; at water depths below $15 \mathrm{~m}$ this fraction amounts to $25-50 \%$.

The $0.25-0.50 \mathrm{~mm}$ fraction is widely distributed in the whole investigation area, forming an up to $3 \mathrm{~km}$ wide NE-SW belt along the waterline of Nõva Bay. The maximum content (up to $75 \%$ ) of this fraction occurs in the central part of the bay, decreasing towards the open sea. In fact, medium sand is the main component of the bottom deposits in Nõva Bay. It is abundant in bottom deposits (up to 65\%) also near Toomanina Cape, forming an approximately $2.5 \mathrm{~km}$ long belt towards the northeast of the cape and along the western shore of Keibu Bay. The content of the fraction decreases towards the open sea, particularly towards Keibu Bay. The distribution pattern of medium sand in Keibu Bay is more variable. The maximum content (up to 50\%) of medium sand is recorded in the area bordering Toomanina Cape, as well as in the central part and near the eastern shore of the bay.

Coarse and very coarse sand $(0.5-2.0 \mathrm{~mm})$ is quite common in the bottom deposits of the investigated area (max $80 \%$ ), forming a wide NE-SW belt along the boundary of the bay mouths and the open sea. In the northeastern part of the area this belt is related to the water depth interval of $15-20 \mathrm{~m}$ and in the southwestern part to the interval of 10-15 m. Higher contents of this fraction are recorded also in the central part of Keibu Bay (up to 70\%) and on a small shoal in the eastern part of the bayhead.

The proportion of the gravel fraction $(>2 \mathrm{~mm})$ is small. Gravel has been washed out from tills or has formed as a result of bedrock erosion. The deposits with an increased gravel content are found near the underwater shoals or bedrock outcrops on the shore, as a rule, in the vicinity of till. The content of gravel in bottom deposits (up to 70\%) is higher also on the eastern slope of Sundgrund Bank, and on Ristinina and Põõsaspea capes. The gravel-rich deposits are 


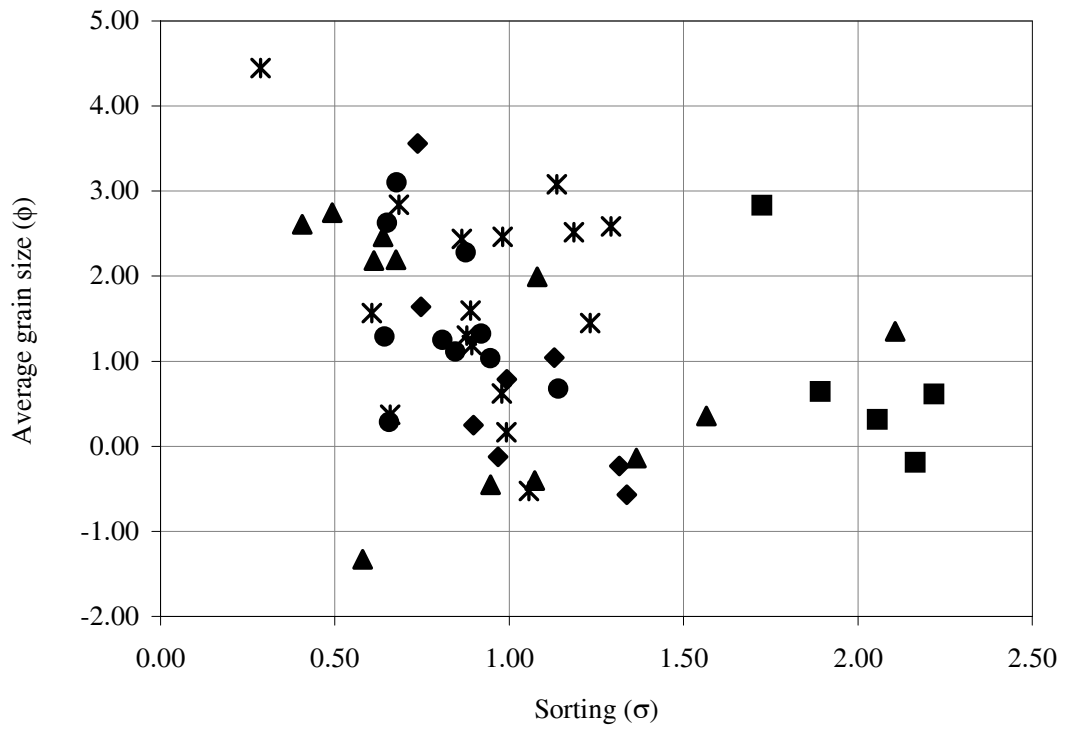

$\boldsymbol{\Delta}$ depth 0-2 m $\bullet$ depth 2-5 m $\boldsymbol{*}$ depth 5-10 m $\bullet$ depth 10-15 m $\boldsymbol{\square}$ depth $>15 \mathrm{~m}$

Fig. 13. Grain size and sorting of the bottom deposits of Keibu Bay.

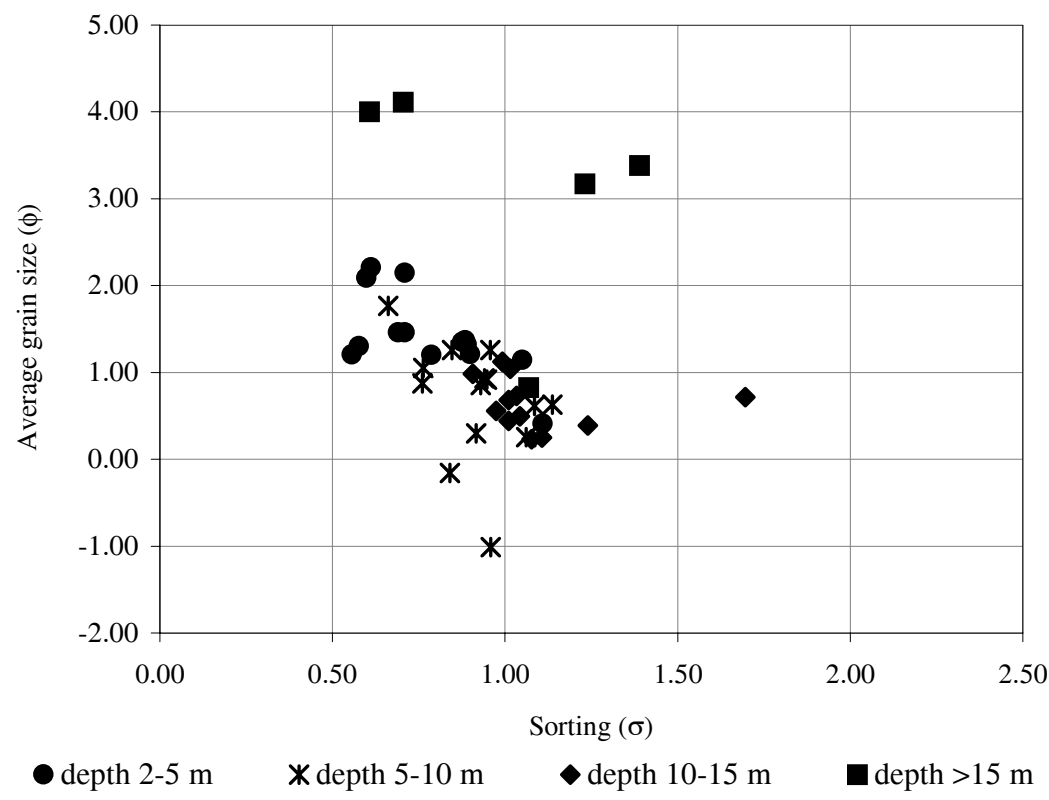

Fig. 14. Grain size and sorting of the bottom deposits of Nõva Bay. 
characterized by the specific shapes of the grain-size distribution curves that are clearly distinguished in the diagrams of statistical moments (Figs. 11-14). The samples from the described areas can be easily distinguished by their grain-size distribution curves (Figs. 11 and 12) as well as on the ternary diagram (Fig. 9).

\section{CONCLUSIONS}

The bottom deposits of Keibu Bay and Nõva Bay consist mainly of sand. In Nõva Bay medium sand prevails, while in Keibu Bay different fractions are encountered. Thus, it can be assumed that in Keibu Bay several sediment sources exist, and the sedimentary processes and the resultant distribution of bottom deposits are more variable (Wegner 2000).

The deposits are well- to medium-sorted inside the bays, while the sorting varies towards the open sea. The sediments dominated by finer fractions (fine and medium sand) are mainly well- to medium-sorted. High variation in sorting is probably due to the presence of gravel in some samples. Poor sorting of deposits in Keibu Bay could be due to the vicinity of the sediment source: new material is constantly supplied from the erosion areas.

Coarse sand and gravel are primarily distributed on underwater shoals, especially near Sundgrund Bank to the north of Toomanina Cape. In such areas residual sediments likely occur, i.e. finer fractions have been washed out, carried away and deposited in areas with suitable hydrodynamic conditions (deeper water, less influence of wave action). The amount of coarser fractions is higher also to the west of Ristinina Cape and to the east of Toomanina and Põõsaspea capes.

Medium sand is the most frequent and commonly prevails in the observation area, especially in Nõva Bay, where its proportion in bottom deposits exceeds $50 \%$ in the central part of the bay and near Toomanina Cape. Bottom deposits of the area bordering with the open sea (mainly in the northern part of Nõva Bay) are commonly dominated by silt and fine sand fractions.

Although the distribution of different fractions in Keibu Bay is mosaic, no clearly expressed correlation with water depth is recorded. Consequently, the formation of bottom deposits may have been influenced by currents and wave activity, but the erosion areas are located near the deposition area - inside the bay (till and varved clay exposed on the seafloor) or on bordering peninsulas (bedrock). Therefore there are permanent sediment suppliers, and currents and waves are only re-distributing the material within the bay.

In Nõva Bay the content of finer fractions in bottom deposits increases towards deeper water and the sorting of sediments varies less than in Keibu Bay. The reason for this could be that Nõva Bay is more exposed to wind and wave action, i.e. to more active hydrodynamic conditions, which favours stronger "washing" of the deposits. 


\title{
ACKNOWLEDGEMENTS
}

The study was financed by the EU project MAST-III IC20-CT-96-0080. The authors are sincerely grateful to the crew of the r/v Littorina for their support and to Dr. Avo Miidel who kindly read the manuscript and made several valuable suggestions.

\section{REFERENCES}

Friedman, G., Sanders, J. E. \& Kopaska-Merkel, D. C. 1992. Principles of Sedimentary Deposits. Macmillan Publishing Company, New York.

Hjulström, F. 1938. Transportation of detritus by moving water. In Recent Marine Sediments (Trask, P. D., ed.), pp. 4-31. Tulsa.

Jõgi, J. \& Tarand, A. 1995. Contemporary climate. In Estonia. Nature (Raukas, A., comp.), pp. 183-216. Valgus Publishers, Estonian Academy Publishers; Tallinn.

Komar, P. D. 1976. Beach Processes and Sedimentation. Prentice Hall, New Jersey.

Kotta, J., Kotta, I. \& Kask, J. 1999. Benthic animal communities of exposed bays in the western Gulf of Finland (Baltic Sea). Proc. Estonian Acad. Sci. Biol., 48, 107-116.

Lewis, D. N. \& McConchie, D. 1994. Analytical Sedimentology. Chapman \& Hale, New-York.

Lutt, J. 1992. Bottom deposits. In Geology of the Gulf of Finland (Raukas, A. \& Hyvärinen, H., eds.), pp. 158-218. Estonian Academy of Sciences, Academy of Finland; Tallinn (in Russian).

Lutt, J. \& Raukas, A. (eds.). 1993. Geology of the Estonian Shelf. Estonian Geological Society, Tallinn.

Paap, Ü. 1969. About the grain-size distribution statistical parameters of Quaternary deposits in NE Estonia. Eesti NSV TA Toim. Keemia Geol., 18, 191-205 (in Russian).

Raukas, A. \& Hyvärinen, H. (eds.). 1992. Geology of the Gulf of Finland. Estonian Academy of Sciences, Tallinn (in Russian).

Raukas, A. \& Teedumäe, A. (eds.). 1997. Geology and Mineral Resources of Estonia. Estonian Academy Publishers, Tallinn.

Schwarzer, K. 1989. Sedimentdynamik in Sandriffsystemen einer tidefreien Küste unter Berücksichtigung von Rippströmen. Berichte/Reports. Geol.-Paläontol. Inst. Univ. Kiel, 33.

Seibold, E. \& Walger, E. 1962. Ein erster Versuch mit Luminophoren zur Untersuchung der Sandwanderung in der Kieler Förde. Meyniana, 12, 1-8.

Vallner, L., Sildvee, H. \& Torim, A. 1988. Recent crustal movements in Estonia. J. Geodyn., 9, 215-223.

Wegner, C. 2000. Quaternary Subsurface and Recent Sediment Distribution in Nõva and Keibu Bays (NW Estonia). MSc. Thesis, Institute of Geosciences, University of Kiel.

\section{Setete kujunemisest Nõva ja Keibu lahes (Loode-Eesti) ning nendega piirnevas avamere osas}

\author{
Jüri Kask, Tuuli Kalberg, Aado Talpas, Klaus Schwarzer ja \\ Carolyn Wegner
}

On uuritud Loode-Eestis paiknevate Nõva ja Keibu lahe põhjasetete lõimist ja käsitletud lõimisefraktsioonide jaotust rannikumere eri sügavusvahemike setetes ja võrdlevalt mõlemas lahes. Setete lõimise uurimiseks kasutati tsentraalsete 
statistiliste momentide meetodit, mille põhjal koostati lõimise jaotuskõverad ja kumulatiivsed kõverad. Keibu ja Nõva lahe põhjasetetest moodustab 80-100\% liiv, aleuriidi ja kruusa levik on väike (vastavalt kuni $7 \%$ ja $3 \%$ ). Nõva lahes valdab keskmiseteraline liiv, lõimisefraktsioonide jaotus on ühtlasem ja setete lõimis korreleerub sügavusega. Keibu lahe põhjaseteteks on erineva terasuurusega liivad, mis jaotuvad korrapäratult. Lahtede suudmete ja avamere piiril levib rannajoonega paralleelne jämedateralise liiva vöönd. Viimasest mere pool esineb merepõhjas aleuriit ja peliit. 